Article

\title{
Demarketing Tourism for Sustainability: Degrowing Tourism or Moving the Deckchairs on the Titanic?
}

\author{
C. Michael Hall ${ }^{1,2,3,4, *(D)}$ and Kimberley J. Wood ${ }^{1}$ (D) \\ 1 Department of Management, Marketing and Entrepreneurship, University of Canterbury, \\ Christchurch 8140, New Zealand; kim.wood@pg.canterbury.ac.nz \\ 2 Department of Service Management and Service Studies, Lund University, Campus Helsingborg, \\ 25108 Helsingborg, Sweden \\ 3 Geography Research Unit, University of Oulu, 90014 Oulu, Finland \\ 4 Ekonomihögskolan, Linnéuniversitet, Universitetskajen, Landgången 6, 39182 Kalmar, Sweden \\ * Correspondence: michael.hall@canterbury.ac.nz
}

Citation: Hall, C.M.; Wood, K.J.

Demarketing Tourism for

Sustainability: Degrowing Tourism or

Moving the Deckchairs on the

Titanic? Sustainability 2021, 13, 1585.

https://doi.org/10.3390/su13031585

Academic Editors: Joseph M. Cheer, Sonya Graci and Claudia Dolezal

Received: 15 January 2021

Accepted: 29 January 2021

Published: 2 February 2021

Publisher's Note: MDPI stays neutral with regard to jurisdictional claims in published maps and institutional affiliations.

Copyright: (c) 2021 by the authors. Licensee MDPI, Basel, Switzerland. This article is an open access article distributed under the terms and conditions of the Creative Commons Attribution (CC BY) license (https:/ / creativecommons.org/licenses/by/ $4.0 /)$.

\begin{abstract}
Demarketing is generally recognized as that aspect of marketing that aims at discouraging customers in general or a certain class of customers in particular on either a temporary or permanent basis and has been increasingly posited as a potential tool to degrow tourism and improve its overall sustainability, particularly as a result of so-called overtourism. The paper provides an overview of the various ways in which demarketing has been applied in a tourism context and assesses the relative value of demarketing as a means of contributing to sustainability and degrowing tourism. It is argued that demarketing can make a substantial contribution to degrowing tourism at a local or even regional scale, but that the capacity to shift visitation in space and time also highlights a core weakness with respect to its contribution at other scales. The paper concludes by noting that the concept of degrowth also needs to be best understood as a continuum of which demarketing is only one aspect.
\end{abstract}

Keywords: social marketing; upstream demarketing; downstream demarketing; tourism system; sustainable tourism

\section{Introduction}

Although it may seem unusual to be discussing degrowth following what has been a metaphorical and actual plague year for tourism, it can be argued that the experiences of COVID-19 by tourism destinations has only heightened the need to respond to the core imperative of sustainable tourism: How do we get an appropriate balance between tourist demand and consumption and the capacity of a destination and the tourism system to supply tourist experiences without running down natural and social capital? This question has, in various related forms, been at the core of issues as to the sustainability of tourism for many years [1]. From the concerns over the so-called "golden hordes" on destinations and their carrying capacity in the 1970s through to more contemporary debates regarding overtourism [2-5], numerous researchers and many in communities that have become destinations, have sought to respond to the issue of the appropriate balance between community needs, environmental conservation and economic development. Indeed, issues over the shared use of public and private space and social distancing under COVID-19 only reinforce the need to better manage issues of supply, demand and capacity rather than to ignore them [6].

This is, of course, not as easy a question as it may first appear. Not only is it a question of what is being balanced but also whose perceptions of what is an appropriate balance we are dealing with. Furthermore, even when there is broad consensus as to the need for balance in the sense of not exceeding planetary limits, there may be substantial disagreement as to how this may be reached in terms of what is an acceptable approach for 
different stakeholders. These questions of sustainability are not isolated to tourism. They are arguably being played out in nearly all economic sectors at various scales and highlight the difficulties in developing and adopting effective sustainability strategies, especially with respect to specific concerns such as climate change and biodiversity loss [7].

One strategy that has been increasingly gaining attention in thinking about sustainability, including with respect to tourism [8-11], is that of degrowth [12]. Degrowth, also referred to as décroissance, is the reduction in the energy and resource flows in an economy to a sustainable level which no longer draws down natural capital [13-16]. The term is often associated with economic contraction or downscaling but is actually more accurately understood more in terms of "rightsizing" an economy so as to achieve a better balance between resource use and supply. Degrowth is not a specific theory but is instead an umbrella term or, more provocatively, a "missile term" [16] with which to attack growthism [17]. As Latouche described it, degrowth is "a political slogan with theoretical implications" [18] (p. 7).

There are a number of streams of sustainability thought that are often closely associated with degrowth thinking, including steady state economics [19,20], the creation of "prosperity without growth" [21], voluntary simplicity [22], and the Latin American notion of the good life and collective wellbeing known as Buen Vivir [23-25]. These streams of thought are very much interconnected. O'Neil, for example, saw degrowth as part of a transition to a steady state economy [26]. Similarly, these perspectives are also related to the growing interest in post-growth perspectives that have as their central focus the reimagining of economic, political and social relations to ensure that humanity stays within planetary capacities, although often retaining a number of elements of capitalism [27-29].

The degrowth literature is rich in critique and debate regarding the negative effects of a growth-oriented economy as well as particular components of what a degrowth economy might look like. However, there is a lack of analysis of how a transition from growth to degrowth might be achieved and the nature of the changes required [30]. In an organizational studies context, for example, Banerjee et al. [29] call of the need to abandon "an economy based on accumulation in favor of embracing distribution, creating an economy of restoration rather than extraction, managing a shift from ideals of competition to ideals of cooperation, and from consumerism to values based on sufficiency". Yet such a shift in political economy clearly runs substantially against mainstream economics and politics [31] Even though the effects of COVID-19 have reemphasized the importance of the state in tackling crises, it does not necessary follow that after years of the dominance of neoliberal thought in public, business and, to a lesser extent, academic life, that hesitancy over expanding the regulatory role of the state in order to control anthropogenic change will suddenly disappear. Indeed, it needs to be remembered that some of the original critiques of the limits to growth were written at a time when the Keynesian notion of the state still dominated and before economic growth came to be equated with redistribution [32].

It is therefore unlikely, despite the seriousness of the sustainability problem, that an attachment to growth will disappear quickly. Institutional change tends to be slow and there are many interests and stakeholders that believe they benefit from and favor the status quo or gradual change at best [30]. Therefore, a substantial issue with respect to the application of any degrowth and sustainability transition strategy is what policy tools or mechanisms are acceptable to stakeholders and economic interests and able to be implemented [33]. Ecoefficiency remains important, even though by itself it is not sufficient to lead to substantial reductions in the drawdown of natural capital. Several commentators $[8,21,34,35]$ have also noted the importance of changes in consumer behavior in order to complement efficiency strategies and focus more on sufficiency by which basic wellbeing needs are met.

In the tourism context, such considerations have engendered interest in behavioral and social marketing interventions to encourage behavioral change for sustainability [36-39]. Although potentially limited in their overall effects on sustainable behaviors, such "common sense" approaches to behavior change [40] serve as a middle path in state interventions 
between education and regulation that can potentially achieve significant stakeholder buyin [38]. Hall argues that one of the reasons why governments are willing to support behavioral economic interventions, such as nudging and downstream consumer-oriented social marketing, is that they do not entail substantial institutional change or shifts in modes of governance $[38,39]$. Nevertheless, they may potentially serve to nudge socioeconomic systems along potentially more sustainable trajectories. However, degrowth approaches generally suggest downscaling the role of markets and commercial exchanges in society [41], meaning that the potential role of marketing as a degrowth tool is hardly ever discussed. In some ways such a situation is a little surprising given the centrality of changes in consumption patterns and consumer behavior in degrowth thinking, although it may also reflect a common, though misplaced view, that marketing is a commercial tool geared towards increasing rather than right-sizing consumption.

One area of marketing that has started to garner some interest with respect to its potential contribution to sustainability and degrowth in a tourism context is that of demarketing [38,42-47], which is primarily concerned with achieving a better balance between supply and demand [38]. Therefore, this paper examines the potential role of demarketing in tourism degrowth strategies and its contribution to more sustainable forms of tourism. It first discusses the concept of demarketing and its definition, before looking at what it does and how it is applied. It then comments on its potential effectiveness and issues in its evaluation before providing some concluding observations.

\section{Demarketing}

Demarketing was originally defined by Kotler and Levy as "that aspect of marketing that deals with discouraging customers in general or a certain class of customers in particular on either a temporary or permanent basis" [48] (p. 76). Some authors see demarketing as being the opposite of marketing [49] or even antimarketing [50]. However, this arguably reflects a standard misunderstanding of what marketing is and framing it only in terms of its commercial application to encourage consumption [51]. Hall, for example, explicitly emphasizes that demarketing is not the opposite of marketing, but rather a "specific application of marketing principles" [38] (p. 138) that is "as relevant to controlling and/or reducing demand as it is for increasing demand" [38] (p. 140). Undoubtedly a reduction in visitor numbers has been identified as significant for some destinations. However, simply reducing numbers per se is potentially an unsophisticated strategy as it just focuses on growth alone in term of arrivals. Any attempt to better balance supply and demand in terms of tourism, therefore, needs to consider more substantial questions of what exactly is tourism being used for and then build from that to identify desirable and undesirable markets and their characteristics, whether it be expenditure, behaviors, periods and places of demand, and the associated environmental, economic and social costs. Therefore, regular marketing strategies apply when demand is negative, non-existent, latent or faltering, and demarketing and related strategies when it is irregular, seasonal, excessive, or inappropriate [38,52].

Demarketing has historically been applied in a social marketing context to areas regarded as social ills or antisocial behavior such as gambling, drug use (e.g., alcohol, tobacco, opioids, heroin), prostitution and trafficking, graffiti and pirated goods [53-55]. However, as the concept developed it was increasingly adopted to help manage environmental issues by modifying and/or reducing consumer demand [56,57]. As a result, demarketing gradually became of interest to tourism researchers who were seeking ways by which to limit the environmental impacts of tourism [58-63], particularly since the emergence of overtourism as a high-profile research concern [64-66].

Table 1 identifies the four different demand states that demarketing primarily responds to $[$ After $[38,52,58]]$. However, seasonal and irregular demand are more correctly described as being primarily tackled by synchromarketing, which seeks to appropriately match demand and supply over time (and, therefore, also over space with respect to where demand occurs at a given time). Although demarketing also has a role to play here with 
some destinations seeking to change their attractiveness to different markets. For example, the head of Amsterdam Marketing, Van der Avert, told the World Tourism Forum: "We don't spend even $€ 1$ in marketing Amsterdam anymore. We don't want to have more people. We want to increase the quality of visitors-we want people who are interested in the city, not who want it as a backdrop for a party" [67].

Inappropriate demand (originally also termed unwholesome demand [52]) is often characterized by countermarketing strategies, especially when the product remains legal, e.g., campaigns that encourage people to fly or consume less. In a tourism context overfull demand equates well with the notion of overtourism, but because of the seasonal nature of tourism, much of what is regarded as overtourism occurs only for a limited time but on a regular, annual basis [68-70]. Temporary over demand or a large mismatch between demand and supply may also occur as a result of non-regular events at a location. These may be because of natural disasters [71]; one-off festivals or events [72]; the sudden imposition of sanctions, boycotts, or buycotts [73]; or sudden popularity on social media [74].

Table 1. Demarketing approaches towards balancing demand.

\begin{tabular}{|c|c|c|c|c|}
\hline Demand State & Characteristic & Tourism Context & Marketing Task & Exemplar Studies \\
\hline $\begin{array}{l}\text { Overfull demand } \\
\text { (overtourism) }\end{array}$ & $\begin{array}{c}\text { Demand exceeds the level } \\
\text { at which a tourism } \\
\text { business or destination } \\
\text { feels able or motivated to } \\
\text { supply it. }\end{array}$ & $\begin{array}{l}\text { Tourist demand for a } \\
\text { destination, site or } \\
\text { experience reaches a level } \\
\text { that results in negative } \\
\text { environmental, economic } \\
\text { and/or social impacts and } \\
\text { experiences. }\end{array}$ & $\begin{array}{l}\text { Demarketing } \\
\text { The core marketing task is } \\
\text { to permanently or } \\
\text { temporarily discourage all } \\
\text { or specific customer } \\
\text { segments. }\end{array}$ & $\begin{array}{c}\text { Use of pricing, timed } \\
\text { ticketing, and changed } \\
\text { promotion strategies to } \\
\text { manage visitors at } \\
\text { Sissinghurst Castle }[75,76] \\
\text { this paper]. }\end{array}$ \\
\hline $\begin{array}{l}\text { Seasonal overfull demand } \\
\text { (temporary overtourism) }\end{array}$ & $\begin{array}{l}\text { The pattern of demand } \\
\text { over time and space is } \\
\text { marked by regular } \\
\text { fluctuations that are } \\
\text { relatively consistent with } \\
\text { the pattern of supply, } \\
\text { although excess and } \\
\text { limited capacity to supply } \\
\text { the product exist at certain } \\
\text { times of the year. }\end{array}$ & $\begin{array}{l}\text { Although demand has a } \\
\text { regular pattern over time, } \\
\text { there are often periods at } \\
\text { which infrastructure and } \\
\text { resources are over and } \\
\text { underutilized. Marketing } \\
\text { can be used to attract } \\
\text { visitors in shoulder and } \\
\text { off seasons to provide } \\
\text { benefits over a longer } \\
\text { period of time. }\end{array}$ & $\begin{array}{c}\text { Synchromarketing } \\
\text { The movements of supply } \\
\text { and demand require better } \\
\text { synchronization. Given } \\
\text { the regularity of demand } \\
\text { this may be done by } \\
\text { seeking ways of extending } \\
\text { shoulder seasons or } \\
\text { hosting special events or } \\
\text { lowering prices in periods } \\
\text { of otherwise low demand. }\end{array}$ & $\begin{array}{l}\text { Combatting seasonality in } \\
\text { nature-based tourism in } \\
\text { Iceland [68-70]. }\end{array}$ \\
\hline Irregular demand & $\begin{array}{l}\text { Temporal and spatial } \\
\text { demand is marked by } \\
\text { volatile fluctuations that } \\
\text { depart from the temporal } \\
\text { and spatial pattern of } \\
\text { supply. }\end{array}$ & $\begin{array}{l}\text { Unexpected variations in } \\
\text { demand can lead to } \\
\text { problems of temporary } \\
\text { overfull or faltering } \\
\text { demand, e.g., those } \\
\text { created by crisis events } \\
\text { such as earthquakes. }\end{array}$ & $\begin{array}{l}\text { Synchromarketing } \\
\text { The movements of supply } \\
\text { and demand require better } \\
\text { synchronization. This is } \\
\text { often done by changing } \\
\text { product, promotion or } \\
\text { price characteristics. }\end{array}$ & $\begin{array}{l}\text { Destination marketing } \\
\text { following the } \\
\text { Christchurch earthquakes } \\
\text { [71]. }\end{array}$ \\
\hline Inappropriate demand & $\begin{array}{l}\text { Any positive demand is } \\
\text { excessive because of the } \\
\text { undesirable qualities } \\
\text { associated with the } \\
\text { product. }\end{array}$ & $\begin{array}{l}\text { Examples include site use } \\
\text { or user behaviors that are } \\
\text { inappropriate, e.g., } \\
\text { vandalism; as well as sin } \\
\text { products such as gambling } \\
\text { and prostitution. }\end{array}$ & $\begin{array}{l}\text { Countermarketing } \\
\text { (unselling) } \\
\text { Using social marketing to } \\
\text { minimize the extent of } \\
\text { inappropriate demand } \\
\text { through various } \\
\text { interventions. }\end{array}$ & $\begin{array}{l}\text { Demarketing sex tourism } \\
\text { [77]; tourism } \\
\text { opportunities suggested } \\
\text { as an alternative to } \\
\text { gambling [78]. }\end{array}$ \\
\hline
\end{tabular}

Differentiating between the demand states is also important because it serves to reflect the different goals and, therefore, strategies that may exist in countering demand imbalance. For example, the goal of synchromarketing in tourism is primarily focused on the numbers of tourists, while demarketing takes a broader approach to also influence the different market segments and behaviors [38]. This means that demarketing may be used, for example, to attract more tourists from high spending markets and less from lower, so that even though absolute tourism numbers may fall, average expenditure per visitor increases and overall income from tourism may even increase [79]. For instance, one of the first examples of demarketing in tourism was the attempt by the Republic of Cyprus to exclude groups normally associated with mass tourism through selective advertising 
and the raising of prices [80]. The demand problem may also shift over time from one of overfull to inappropriate demand. For example, the demarketing of Uluru, Australia, in response to inappropriate tourist behavior by visitors climbing the sacred site [81], to the point where they are now banned from climbing. Nevertheless, the Uluru example also potentially points to a changing emphasis in the focus of demarketing in tourism from just focusing on the consumer to seeking to manage supply and demand as part of a destination tourism system.

\section{What Is Being Demarketed?}

Concern over the capacity of attractions, sites and destinations to cope with tourism growth in both short and long-term has long been a major focus of tourism research, especially that which is concerned with sustainability, impacts and carrying capacity [1]. Much of this work has historically been site focused [58,64], with national parks and heritage sites receiving substantial emphasis $[59,63,81,82]$. Such a situation perhaps reflects Drugova et al.'s observation that the "overcrowding of nature tourism sites has been documented on every continent" [65] (p. 2) Nevertheless, in recent years there has been a much stronger focus on demarketing urban places and locations [62,83], especially in response to the pressures of overtourism $[2,84,85]$, to the stage where they have become the major institutional focus for overtourism [86,87].

However, the focus is shifting further as it is no longer just on demarketing places and attractions but also on travel methods and accommodation chosen as such activities also generate emissions of greenhouse gases that have a global impact [88]. Significantly, such concerns are not new with the notion of demarketing first emerging at the time of concerns over the limits to growth and oil crises [52,89]. Yet, the scale of anthropogenic change is much greater 50 years on leading to renewed interest in the possibilities of demarketing to reduce harmful consumption and damage to natural resources [66,90,91].

\section{How Is Demarketing Achieved?}

In general, demarketing adopts marketing tactics to reduce the number and/or nature of demand for a tourist product at a particular location and time. Table 2 identifies some of the most common elements of demarketing in the literature positioned in terms of the 4Ps of marketing. Nevertheless, there remains different perspectives on the attributes of demarketing in their application. For example, in the case of demarketing nature-based tourism, Magalhães et al. [92] argue that measures that involve the prohibition of access, or limitations of visitor numbers, in space or time, are not demarketing measures because they do not solve the environmental problems caused by too many visitors and may also discourage other customers. Instead, they suggest that "pre-queuing or reservations are what constitutes the true measure of demarketing" [92] (p. 936).

Wall [93] also includes the use of public information and educational measures, together with more regulatory approaches such as taxation and legislation as part of demarketing measures. Although possibly of value, such measures are usually not included as forms of social marketing [38]. Nevertheless, education is noted by Beeton [60] and Fullerton et al. [94], who also explicitly focus on encouraging specific desirable markets while discouraging undesirable ones and paying particular attention to the fragility of areas, making access to such sites more difficult while simultaneously promoting more robust ones (see also [95]).

Milano et al. [10] studied the efforts of Barcelona officials in degrowing the tourism industry. The need for demarketing emerged from the SET (South Europe cities facing Touristification) manifesto, which highlighted several issues due to "touristification", such as: the decrease in availability of, and right to, housing for residents, the transformation of local trade places, the overcrowding of public spaces and public transport, and the increase in pollution and waste. It is claimed that these issues are common problems to all the members of the city network [96]. Significantly, such measures highlight the broadening of a more limited notion of demarketing to one that fits in more within the degrowth frame as 
it also raises issues of the importance of independent, robust data collection and indices development; the need for alternative economic and social development models; local government funding of tourism; employment conditions in the tourism industry; and resident community involvement in destination governance processes.

Table 2. Relationship of marketing mix to attraction and destination demarketing measures.

\begin{tabular}{|c|c|}
\hline Demarketing Measure ${ }^{1}$ & Elements of Marketing Mix \\
\hline $\begin{array}{l}\text { Use pricing as a demand management tool, e.g., charging for } \\
\text { access or time spent. }\end{array}$ & Price \\
\hline $\begin{array}{l}\text { Using a time booking, queuing system to increase the time } \\
\text { and opportunity costs of the experience. }\end{array}$ & Price \\
\hline $\begin{array}{l}\text { Limiting promotional strategy to selected and specialized } \\
\text { media channels or cease promotion altogether. }\end{array}$ & Promotion, Place \\
\hline $\begin{array}{l}\text { Promoting and communicate need to conserve through } \\
\text { minimal impact and sustainable development. }\end{array}$ & Promotion \\
\hline $\begin{array}{l}\text { Communicating the environmental degradation and negative } \\
\text { social effects on the host community that could occur if too } \\
\text { many people frequent the area. }\end{array}$ & Promotion, Place \\
\hline $\begin{array}{l}\text { Communicating any restrictions or difficulties associated with } \\
\text { travel to the area. }\end{array}$ & Promotion, Place \\
\hline $\begin{array}{l}\text { Provide alternative locations or experiences for visitors and } \\
\text { communicate them. }\end{array}$ & Place, Product, Promotion \\
\hline $\begin{array}{l}\text { Zoning policies are applied to limit activities to some } \\
\text { locations and not others-may be undertaken seasonally. }\end{array}$ & Place, Product \\
\hline Limit accommodation, parking, entrance or area access & Place \\
\hline $\begin{array}{l}\text { Permit certain activities only for a set duration of time and/or } \\
\text { with supervision. In some cases, particular activities may } \\
\text { even cease. }\end{array}$ & Product \\
\hline Promote and develop alternative site uses. & Promotion, Product \\
\hline $\begin{array}{l}\text { Promote virtual experiences as a substitute and/or } \\
\text { complementary experience. }\end{array}$ & Promotion, Product \\
\hline $\begin{array}{l}\text { Utilize interpretation as a management tool to reduce } \\
\text { undesirable and inappropriate behaviors and develop new } \\
\text { product relationships in order to reduce visitor pressures. }\end{array}$ & Promotion, Product \\
\hline
\end{tabular}

The SET [96] suggestions for appropriate responses to tourism pressures are also substantially stronger in terms of community responsiveness than the proposals of Koens and Postma [98] who highlighted ten main strategies that emerged from their study of overtourism in Europe: (1) spreading visitors around the city and beyond; (2) time-based rerouting; (3) regulation; (4) creating itineraries; (5) visitor segmentation; (6) making residents benefit from the visitor economy; (7) creating city experiences that benefit both visitors and local residents; (8) communicating with and involving local stakeholders; (9) communicating with and involving visitors; (10) improving city infrastructure and facilities [4]. These suggestions are significant because they have also been adopted by the UNWTO [87] in their proposals for responding to overtourism. Significantly, such measures highlight the hesitancy of the tourism sector and its institutional bodies to adopt pricing mechanisms, including taxes, to better manage tourism demand [99]. As Drugova et al. observed, "The most common demarketing dimension used by (or recommended to) policymakers is nonprice mechanisms designed to allocate visitors over space and time" [65] (p. 4), including with respect to the adoption of so-called "smart city strategies" to provide 
more detailed information on visitor numbers, behaviors, and flows in order to improve their management [4].

\section{The Effectiveness of Demarketing}

Given the range of demarketing tools available, an important issue that then presents itself is how to measure the effectiveness of particular demarketing campaigns. From the studies conducted, very few have provided a follow-up study to measure the effectiveness of demarketing strategies. This may possibly be due to a lack of a clear framework for the "demarketing" concept in a tourism context beyond commonly collected statistics such as visitor numbers, expenditures and market characteristics. Longitudinal surveys of resident community responses to tourism that are supported by government agencies in the same way that tourism data are gathered, for instance, are rare, with one of the few examples being found in Iceland [70]. Nevertheless, even where data are collected, they may not have been done so to directly monitor and evaluate the success of a demarketing campaign, nor is there any guarantee that there is an appropriate social marketing program that links the goals, tools and results of the marketing campaign to the specific problem that demarketing is trying to attend to.

One of the major issues in evaluating the effectiveness of demarketing campaigns is the lack of evaluation. One of the few tourist attractions for which it is possible to observe at least some of the effects of a conscious effort to demarket is the National Trust property of Sissinghurst in the UK.

\subsection{Demarketing Sissinghurst}

Sissinghurst Castle is an historical monument, garden and farm located in Kent, England. Sissinghurst was purchased by author and poet Vita Sackville-West and her husband author and politician Harold Nicolson in 1930. Vita Sackville-West was a lover of Virginia Woolf, while her husband was also bisexual [100]. The identity, literary and media connections to Sackville-West and Nicholson are important because they add to the location's attractiveness to visitors [101]. The original Jacobean house was run down and required considerable expenditure to improve and maintain. In addition, the immediate grounds were transformed into a fine and extremely influential series of gardens and walks which were first opened to the public in the late 1930s. Upon Vita's death in 1962, Harold could not maintain the intensive upkeep of the garden and decided to pass ownership to the National Trust in 1967, with the family retaining rights of access to the house. Visitation rose from a maximum of around 28,000 visitors during the era of private ownership to 67,000 in 1967, the first year it was advertised to National Trust members, and over 91,000 by $1973[75,102]$.

As a result of visitor pressures, the first attempts at active site management began in the 1970s. Beginning with paving and individual site rehabilitation in the early 1970s, a full-service food facility was opened in 1987 and a gift store added in 1988. By 1986, there were more than 140,000 visitors during the open season (April-October), and in 1989, 166,000 people visited [76]. Managers began to realize there was no indication of visitor growth levelling off, and with so many visitors there were clear signs of overcrowding in the five acre (two hectare) garden. This initiated the selection of a set carrying capacity to prevent degradation of the garden. The decision to limit the carrying capacity of Sissinghurst Castle Garden to 400 visitors was made in 1989 and initially relied on self-regulation on the part of visitors [75]. This meant that upon reaching this limit, a wait prior to entry was recommended, although it was not enforced. This strategy proved unsuccessful, as the number of visitors would rise to 700-800 regardless of the level of overcrowding. As well as negative impacts on the condition of the gardens and property, this translated into highly unsatisfactory visitor experiences on peak days as movement became increasingly more difficult and there were no additional site attractions to encourage the dispersal of people. At certain peak times, visitors were becoming unable to negotiate the garden paths 
and were spilling over on to the grass and flower gardens, in the process destroying the very features they had come to observe [76].

To combat overcrowding, help protect the site and provide a better experience for visitors, the National Trust and Sissinghurst Castle management imposed enforceable regulations to limit the extent of public access to the garden. In 1992, a timed entry system commenced. Once the garden capacity had been reached, visitors were given a time to enter the garden. This usually resulted in a $30 \mathrm{~min}$ delay or less. Prior to the implementation of this system, coaches would arrive unannounced with up to 50 passengers [76]. Although the implementation was not initially well received by the tourists held at the gate, it did help to protect the garden. As Benfield emphasized; essentially, the facility had no choice but to delineate carrying capacity limits in order to maintain the physical and experiential sustainability of the garden [76].

However, even given the implementation of a timed entry system, visitor growth continued. The only option to attempt reducing tourist numbers was to formally engage in demarketing. In 1996, between April and October, when the garden was open, 200,000 people visited. It was at this point that the Trust deemed 200,000 people a year to be well beyond the garden's capacity and adopted a demarketing strategy to reduce the number of people visiting the garden [103]. The National Trust ceased all paid advertising of Sissinghurst in 1997. In addition, any magazine features that were planned for the garden were edited in conjunction with the author, where possible, to stress the sensitivity of the garden and the restrictions that were in place [76]. Such measures were also coupled with discontinuation of concessionary visits for tour operators and media, and more effective management of larger groups. In 1998 a survey was conducted to assess visitor management; it was found that while $75 \%$ of the visitors were against a timed entry system, $94 \%$ had experienced no wait to enter the garden, and of the $6 \%$ who did have to wait (usually because of inclement weather), half of them waited less than 30 min [76].

As a further response to tourist pressures on the garden, the National Trust began to encourage the use of 400 acres of woodland on the property for a less intensive gardenvisiting experience [75]. As well as providing a sightseeing opportunity, additional efforts to emphasize the historical dimensions of Sissinghurst sought to give a greater appreciation of the site and diversify the nature of the experience. These were also accompanied by the provision of events and visitation opportunities outside of the peak demand period so as to try and spread demand more over the year as well as provide different experiences. The introduction of these measures along with the provision of relevant information before visiting allowed visitors to actually engage more with the history behind Sissinghurst Castle and expand beyond the garden as being the main visitor focus $[38,101]$.

Following the introduction of these demarketing measures annual visitation stabilized. The timed entry system only had to be utilized during the peak season in June-July, and on warm days that otherwise attracted visitors. By 2011, the timed entry system was discontinued as visitation patterns stabilized and surveys showed a continuing high level of visitor satisfaction [76]. Although this has now been reintroduced as a result of COVID19 as a means to physically distance visitors. However, the subsequent refurbishment and development of Sissinghurst Castle did mean that visitor numbers grew from 170,000 in 2013 to 200,000 in 2017 [104], although the timing of visits was more dispersed over the year than in the 1980s and 1990s. As Philip Barnes, General Manager at the National Trust's Sissinghurst Castle Garden reported to the House of Commons Digital, Culture, Media and Sport Committee, Sissinghurst Castle Garden cannot take any additional visitors during the months of May and June but that "spreading the season across the year is an opportunity for us to manage that sustainability a bit better" [105] (p. 7).

\subsection{The Effectiveness of Demarketing Campaigns}

The Sissinghurst case illustrates the potential of demarketing measures to limit and reallocate demand so as to conserve the attraction resource and still provide a positive visitor experience. However, even though sustainability is a general goal and numbers have 
been held to a point at which they are manageable, fine detail on the relative effectiveness of different marketing methods is unavailable. Outside of tourism, Wall investigated demarketing campaigns targeting three separate issues: binge drinking, smoking, and use of private-cars [93]. These three were individually tested and measured based on both a general audience and the target audience's perceived behavioral change after being exposed to such campaigns. Significantly, there was substantial variation in the relative success of measures. In the case of smoking and binge drinking, the most successful measures were banning of smoking in public and crackdowns on disorderly behavior, and the least successful were helplines and public information (e.g., leaflets), respectively. In terms of campaigns to reduce car use, which is most akin to a tourism related demarketing issue, no campaign was regarded as more than $44 \%$ effective. Of these measures, the levels of effectiveness ranged from road pricing (e.g., tolls) ( $44 \%$ effective) and improvements in public transport ( $38 \%$ effective) through to improved networks of cycle paths ( $22 \%$ effective) and public information (e.g., leaflets) and television (or other advertising) ( $23 \%$ effective). Importantly, such interventions were not measured over the longer term so, therefore, we do not know how effective such marketing interventions were over time. Nevertheless, even when looking through the short-term effects of demarketing, it appears that the relative success of demarketing interventions depends very much on the context in which they occur, both with respect to the specific intervention and site or behavior that is the focus of the intervention and the nature of the tourist market [66].

\section{Discussion and Conclusions}

The paper examined the potential contribution of demarketing to more sustainable forms of tourism and to degrowth strategies in particular. Beeton and Benfield [59] (p. 502) suggested that the use of demarketing in tourism had been mostly unconscious and had "not been adequately recognized or actively pursued as a marketing or management tool". This situation has improved substantially in the past 20 years with demarketing becoming increasingly noted as a management tool for national parks, heritage sites and urban destinations $[38,63,64,81,82]$. Nevertheless, detailed case studies and evaluations of the efficacy of demarketing for tourism are few, especially over the longer term. Significantly, this is not an issue isolated to tourism, with more research on the effectiveness of demarketing practices to change actual behaviors widely recognized as being needed, especially with respect to pro-environmental behavior [90]. Similarly, demarketing measures are also usually associated with particular locations, such as tourist attractions or destinations. Yet, even in the case of the latter, the focus tends to be on particular areas within the destination rather than the destination as a whole [70], raising issues about the scale at which demarketing is and can be applied.

This last observation is extremely important as there is insufficient understanding of how the implementation of demarketing measures at one point in space and time has effects elsewhere within the tourism system. If tourists are being demarketed away from a location where do they go and what will be their impacts? Is demarketing without addressing the overall question of growth in terms of how far, fast and for how long people travel and what they consume merely just moving the deckchairs around on the Titanic, or can the direction of the ship be changed? From a global perspective, improvements in the environmental efficiency or sustainability of a site as a result of demarketing are clearly valuable for the attraction or destination, but when taking in to account the displacement effects of the campaign at a wider scale the absolute effects may be negligible or may even have increased tourism's impacts because the displaced visitors may have travelled further for a substitute experience. Therefore, there is a great need to better understand the potential rebound effects of demarketing and behavioral interventions [106-108] and the interplay between different behavioral interventions and tourist mobility. For example, in response to Van der Avert's views, noted above, on marketing Amsterdam as a destination and limiting the number of visitors while increasing their "quality" so the city does not attract people "who want it as a backdrop for a party", one comment was that "This 
is exactly what the Dutch tourism (Amsterdam citizens) have been doing over the last 40 years in destination countries like Spain" [67].

The focus of demarketing interventions tends to be on consumers and changing the nature of consumption, rather than looking to change the nature of production and the broader tourism system [91]. Interestingly, the limits of demarketing focusing primarily on the consumer have been long recognized. Murray [109] suggested that the original conceptualizations of countermarketing and demarketing as demand-related, discrete marketing functions, were made at a time when the focused lay more upon stopping harmful demand than harmful supply. Anticipating many of the concerns of degrowth thinking and more holistic approaches towards sustainability, Murray argued that demarketing demand and harmful supply offered a foundation for more social activist forms of marketing [109], akin to upstream forms of social marketing and consumer activism that seeks to shift companies and institutions [73]. Nevertheless, while there is clearly interest in more activist approaches to tourism marketing [10,39], the dominant paradigms of tourism marketing, including with respect to the use of demarketing, sit firmly inside non-activist approaches that frame the problem as one requiring improved management rather than a wholesale rethinking of tourism [99]. As Fletcher et al. commented, "to seriously pursue degrowth at both global and most national levels would ... likely require drastic transformation of the tourism industry and its metabolism" [110] (p. 1746).

A key issue, therefore, with respect to the potential contribution of demarketing to degrowing tourism is the scale at which degrowth is targeted. This may also reflect different perceptions of how change occurs. Can sustainable change in tourism occur as the result of market oriented behavioral mechanisms or does it require a more fundamental shift in thinking that seeks to shift practices and the socio-technical institutions within which tourism operates? [33,39]. As noted, the use of demarketing tends to be quite narrow in space and time and limited to specific locations. This has, therefore, meant that, as it is being proposed in the literature and in practice, the majority of demarketing is shifting tourist demand from one location to another, or dispersing demand more in space and time, rather than framing tourism, and tourism growth in particular, as being the problem in absolute terms [79]. Such an approach, which is reflective of many influential tourism industry oriented strategies [86,87], means that consumer oriented downstream demarketing can contribute to degrowing tourism at particular locations but the wider negative contributions of tourism to anthropogenic change at a global scale are not addressed.

As a potential tool for degrowing tourism, demarketing therefore needs to be considered within the context of a range of different interventions which are, in turned, positioned at different scales and with different goals in mind (Table 3). Drawing on previous work on social marketing [38], Table 3 seeks to summarize some of the findings and conclusions of this analysis in relation to the order of change particular interventions represent, the focus of the intervention, time scale, and consideration as to whether the intervention is causing displacement or not.

Downstream demarketing may potentially contribute to greater sustainability of particular locations and products but its capacity to contribute to degrowth at a global scale, like many behavioral interventions, appears limited, if undertaken in isolation from more fundamental changes in the tourism system [106-108]. The reason for this is that it is not possible to continuously displace tourists in space and time without continuing to have negative impacts at a wider scale, and eventually the global scale, even though the situation may have temporarily improved at the location interventions seek to protect. Downstream demarketing is moving the deck chairs on the Titanic. In contrast, upstream demarketing, which seeks to change the overall sustainability of the tourism system, is akin to missing the iceberg. 
Table 3. A continuum of demarketing, behavioral and supply interventions.

\begin{tabular}{|c|c|c|c|c|}
\hline Order of Change & First Order & \multicolumn{2}{|c|}{ Second Order } & Third Order \\
\hline & $\begin{array}{l}\text { Incremental change in } \\
\text { the use of policy and } \\
\text { visitor management } \\
\text { instruments, no overall } \\
\text { questioning of growth }\end{array}$ & \multicolumn{2}{|c|}{$\begin{array}{l}\text { Selection of new policy and visitor management } \\
\text { instruments and techniques but no overarching } \\
\text { paradigm shift. Growth is seen in a more strategic } \\
\text { context, e.g., green growth, efficiency (less } \\
\text { resource use and/or emissions per tourist), greater } \\
\text { returns per tourist with numbers kept at a similar } \\
\text { level (shift to higher yielding tourists) }\end{array}$} & $\begin{array}{l}\text { Policy and planning } \\
\text { paradigm shift towards } \\
\text { degrowth. } \\
\text { Fundamental change in } \\
\text { the socio-technical } \\
\text { system of tourism }\end{array}$ \\
\hline $\begin{array}{l}\text { Primary location of } \\
\text { intervention }\end{array}$ & Site, transport & $\begin{array}{l}\text { Attractions, sites } \\
\text { (especially national } \\
\text { parks), transport }\end{array}$ & $\begin{array}{l}\text { Destination } \\
\text { communities }\end{array}$ & $\begin{array}{l}\text { Destination systems, } \\
\text { global tourism system, } \\
\text { business networks }\end{array}$ \\
\hline $\begin{array}{l}\text { Primary focus for } \\
\text { behavioral intervention }\end{array}$ & Individuals & $\begin{array}{l}\text { Individuals (especially } \\
\text { at attractions and sites) }\end{array}$ & $\begin{array}{c}\text { Individual visitors, } \\
\text { tourism businesses and } \\
\text { organizations, } \\
\text { destination community }\end{array}$ & $\begin{array}{c}\text { Systems of } \\
\text { provision/institutions; } \\
\text { communities, networks }\end{array}$ \\
\hline $\begin{array}{l}\text { Understanding of } \\
\text { decision making }\end{array}$ & $\begin{array}{l}\text { The means for } \\
\text { increasing utility }\end{array}$ & $\begin{array}{c}\text { Dominant paradigm of } \\
\text { "ABC": attitude, } \\
\text { behavior, and choice }\end{array}$ & $\begin{array}{l}\text { Greater emphasis on } \\
\text { psychological needs } \\
\text { (signifiers), behavior } \\
\text { and social contexts } \\
\text { (norms) }\end{array}$ & $\begin{array}{l}\text { Consumption practices, } \\
\text { many of which are } \\
\text { habitual, are } \\
\text { constrained/shaped by } \\
\text { sociotechnical } \\
\text { infrastructure and } \\
\text { institutions }\end{array}$ \\
\hline $\begin{array}{l}\text { Dominant governance } \\
\text { modes }\end{array}$ & Markets & Markets & $\begin{array}{l}\text { Markets, community, } \\
\text { networks }\end{array}$ & $\begin{array}{l}\text { Hierarchies (state), } \\
\text { communities }\end{array}$ \\
\hline $\begin{array}{l}\text { Primary demand side } \\
\text { Interventions }\end{array}$ & Education, labelling & $\begin{array}{l}\text { Downstream } \\
\text { demarketing, use of } \\
\text { promotion, product } \\
\text { and place as a } \\
\text { demarketing tool; focus } \\
\text { on personal norms }\end{array}$ & $\begin{array}{c}\text { Downstream } \\
\text { demarketing, nudging, } \\
\text { greater use of price as a } \\
\text { demarketing tool; } \\
\text { community-based } \\
\text { demarketing/social } \\
\text { marketing; focus on } \\
\text { social norms; } \\
\text { legislation \& regulation }\end{array}$ & $\begin{array}{l}\text { Legislation \& } \\
\text { regulation, use of price } \\
\text { as a demarketing tool, } \\
\text { fundamental changes } \\
\text { to the nature of the } \\
\text { product, marketing to } \\
\text { promote change }\end{array}$ \\
\hline $\begin{array}{l}\text { Primary supply side } \\
\text { Interventions }\end{array}$ & $\begin{array}{l}\text { Education, tax } \\
\text { incentives }\end{array}$ & $\begin{array}{l}\text { Industry } \\
\text { self-regulation, tax } \\
\text { incentives, } \\
\text { synchromarketing } \\
\text { promotion and product } \\
\text { strategies }\end{array}$ & $\begin{array}{c}\text { Industry } \\
\text { self-regulation, } \\
\text { legislation \& regulation, } \\
\text { pricing mechanisms }\end{array}$ & $\begin{array}{l}\text { State: Legislation \& } \\
\text { regulation, taxation, } \\
\text { pricing, short supply } \\
\text { chains, marketing to } \\
\text { promote change } \\
\text { Consumers: Upstream } \\
\text { demarketing, activism, } \\
\text { demands for } \\
\text { fundamental changes } \\
\text { to the nature of the } \\
\text { product }\end{array}$ \\
\hline $\begin{array}{c}\text { Consideration of } \\
\text { displacement effects }\end{array}$ & No & No & Little & Integral \\
\hline
\end{tabular}

The challenge of demarketing, therefore, remains the fundamental issue facing those advocating tourism degrowth $[9,11,111]$ : how to move beyond localized initiatives to create systemic change? Demarketing is clearly not without value and can be a significant contributor to degrowth because of the attention it gives to the social and cultural context of consumption and how this can be used to initiate voluntary change. However, to meet the challenges of overtourism, anthropogenic change and the climate crisis, local interventions at attraction, destinations and the travel stages of tourism need to go hand-in-hand with multi-lateral initiatives at the global scale. 
Author Contributions: Conceptualization, writing-original draft preparation, writing-review and editing, C.M.H. and K.J.W. All authors have read and agreed to the published version of the manuscript.

Funding: This research received no external funding.

Institutional Review Board Statement: Not applicable.

Informed Consent Statement: Not applicable.

Data Availability Statement: Not applicable.

Conflicts of Interest: The authors declare no conflict of interest.

\section{References}

1. Hall, C.M.; Gössling, S.; Scott, D. (Eds.) The Routledge Handbook of Tourism and Sustainability; Routledge: Abingdon, UK, 2015.

2. Adie, B.A.; Falk, M.T.; Savioli, M. Overtourism as a perceived threat to cultural heritage in Europe. Curr. Issues Tour. 2019, 23, 1737-1741. [CrossRef]

3. Perkumiene, D.; Pranskuniene, R. Overtourism: Between the right to travel and residents' rights. Sustainability 2019, 11, 2138. [CrossRef]

4. Camatti, N.; Bertocchi, D.; Carić, H.; Van Der Borg, J. A digital response system to mitigate overtourism. The case of Dubrovnik. J. Travel Tour. Mark. 2020, 37, 887-901. [CrossRef]

5. Milano, C.; Cheer, J.M.; Novelli, M. Introduction. In Overtourism: Excesses, Discontents and Measures in Travel and Tourism; Milano, C., Cheer, J.M., Novelli, M., Eds.; CABI: Wallingford, UK, 2019; pp. 1-17.

6. Capocchi, A.; Vallone, C.; Pierotti, M.; Amaduzzi, A. Overtourism: A literature review to assess implications and future perspectives. Sustainability 2019, 11, 3303. [CrossRef]

7. Bradshaw, C.J.A.; Ehrlich, P.R.; Beattie, A.; Ceballos, G.; Crist, E.; Diamond, J.; Dirzo, R.; Ehrlich, A.H.; Harte, J.; Harte, M.E.; et al. Underestimating the challenges of avoiding a ghastly future. Front. Conserv. Sci. 2021, 1, 1-9. [CrossRef]

8. Hall, C.M. Degrowing Tourism: Décroissance, sustainable consumption and steady-state tourism. Anatolia 2009, 20 , 46-61. [CrossRef]

9. Hall, C.M. Changing paradigms and global change: From sustainable to steady-state tourism. Tour. Recreat. Res. 2010, 35, 131-143. [CrossRef]

10. Milano, C.; Novelli, M.; Cheer, J.M. Overtourism and degrowth: A social movements perspective. J. Sustain. Tour. 2019, 27, 1857-1875. [CrossRef]

11. Hall, C.M.; Lundmark, L.; Zhang, J.J. Tourism and Degrowth: New Perspectives on Tourism Entrepreneurship, Destinations and Policy; Routledge: Abingdon, UK, 2021.

12. Kallis, G.; Kostakis, V.; Lange, S.; Muraca, B.; Paulson, S.; Schmelzer, M. Research on degrowth. Ann. Rev. Environ. Resour. 2018, 43, 291-316. [CrossRef]

13. Kallis, G. In defence of degrowth. Ecol. Econ. 2011, 70, 873-880. [CrossRef]

14. Kallis, G. Degrowth; Agenda Publishing: Newcastle upon Tyne, UK, 2018.

15. Kallis, G.; Kerschner, C.; Martinez-Alier, J. The economics of degrowth. Ecol. Econ. 2012, 84, 172-180. [CrossRef]

16. Hickel, J. What does degrowth mean? A few points of clarification. Globalizations 2020, 1-7. [CrossRef]

17. Daly, H. A further critique of growth economics. Ecol. Econ. 2013, 88, 20-24. [CrossRef]

18. Latouche, S. Farewell to Growth; Polity Press: Cambridge, UK, 2009; p. 7.

19. Daly, H.E. Steady State Economics, 2nd ed.; Island Press: Washington, DC, USA, 1991.

20. Daly, H.E. From Uneconomic Growth to a Steady-State Economy; Edward Elgar: Cheltenham, UK, 2014.

21. Jackson, T.; Senker, P. Prosperity without Growth: Economics for a finite planet. Energy Environ. 2011, 22, 1013-1016. [CrossRef]

22. Hall, C.M. Consumerism, tourism and voluntary simplicity: We all have to consume, but do we really have to travel so much to be happy? Tour. Recreat. Res. 2011, 36, 298-303. [CrossRef]

23. Gudynas, E. Buen vivir: Today's tomorrow. Development 2011, 54, 441-447. [CrossRef]

24. Everingham, P.; Chassagne, N. Post COVID-19 ecological and social reset: Moving away from capitalist growth models to-wards tourism as Buen Vivir. Tour. Geogr. 2020, 22, 555-566. [CrossRef]

25. Ruiz-Ballesteros, E. Community-based tourism and degrowth. In Tourism and Degrowth: New Perspectives on Tourism Entrepreneurship, Destinations and Policy; Hall, C.M., Lundmark, L., Zhang, J.J., Eds.; Routledge: Abingdon, UK, 2021; pp. $170-186$.

26. O'Neill, D.W. Measuring progress in the degrowth transition to a steady state economy. Ecol. Econ. 2012, 84, 221-231. [CrossRef]

27. Blühdorn, I. Post-capitalism, post-growth, post-consumerism? Eco-political hopes beyond sustainability. Glob. Discourse 2017, 7, 42-61. [CrossRef]

28. Jackson, T. The post-growth challenge: Secular stagnation, inequality and the limits to growth. Ecol. Econ. 2019, 156, 236-246. [CrossRef]

29. Banerjee, B.; Jermier, J.M.; Peredo, A.M.; Perey, R.; Reichel, A. Theoretical perspectives on organizations and organizing in a post-growth era. Organization 2020. [CrossRef] 
30. Joutsenvirta, M. A practice approach to the institutionalization of economic degrowth. Ecol. Econ. 2016, 128, 23-32. [CrossRef]

31. Löwy, M. Ecosocialism: A Radical Alternative to Capitalist Catastrophe; Haymarket Books: Chicago, IL, USA, 2015.

32. Meadows, D.H.; Meadows, D.L.; Randers, J.; Behrens, W.W., III. The Limits to Growth: A Report for the Club of Rome's Project on the Predicament of Mankind; Universe Books: New York, NY, USA, 1972.

33. Hall, C.M. Policy learning and policy failure in sustainable tourism governance: From first- and second-order to third-order change? J. Sustain. Tour. 2011, 19, 649-671. [CrossRef]

34. Hall, C.M. Economic greenwash: On the absurdity of tourism and green growth. In Tourism in the Green Economy; Reddy, V., Wilkes, K., Eds.; Earthscan: London, UK, 2015; pp. 339-358.

35. Liegey, V.; Nelson, A. Exploring Degrowth: A Critical Guide; Pluto Press: London, UK, 2020.

36. Truong, V.D.; Hall, C.M. Social marketing and tourism. Soc. Mark. Q. 2013, 19, 110-135. [CrossRef]

37. Borden, D.S.; Coles, T.; Shaw, G. Social marketing, sustainable tourism, and small/medium size tourism enterprises: Challenges and opportunities for changing guest behaviour. J. Sustain. Tour. 2017, 25, 903-920. [CrossRef]

38. Hall, C.M. Tourism and Social Marketing; Routledge: London, UK, 2014.

39. Hall, C.M. Intervening in academic interventions: Framing social marketing's potential for successful sustainable tourism behavioural change. J. Sustain. Tour. 2016, 24, 350-375. [CrossRef]

40. Shove, E. Beyond the ABC: Climate change policy and theories of social change. Environ. Plan. A Econ. Space 2010, 42, 1273-1285. [CrossRef]

41. Sekulova, F.; Kallis, G.; Rodríguez-Labajos, B.; Schneider, F. Degrowth: From theory to practice. J. Clean. Prod. 2013, 38, 1-6. [CrossRef]

42. Canavan, B. Sustainable tourism: Development, decline and de-growth. Management issues from the Isle of Man. J. Sustain. Tour. 2013, 22, 127-147. [CrossRef]

43. Çakar, K.; Uzut, I. Exploring the stakeholder's role in sustainable degrowth within the context of tourist destination governance: The case of Istanbul, Turkey. J. Travel Tour. Mark. 2020, 37, 917-932. [CrossRef]

44. Ballantine, P.W. Domestic tourism as a degrowth strategy. In Tourism and Degrowth: New Perspectives on Tourism Entrepreneurship, Destinations and Policy; Hall, C.M., Lundmark, L., Zhang, J.J., Eds.; Routledge: Abingdon, UK, 2021; pp. $187-202$.

45. Hall, C.M.; Lundmark, L.; Zhang, J.J. Conclusions-Degrowing tourism: Can tourism move beyond BAU (Brundtland-as-Usual)? In Tourism and Degrowth: New Perspectives on Tourism Entrepreneurship, Destinations and Policy; Hall, C.M., Lundmark, L., Zhang, J.J., Eds.; Routledge: Abingdon, UK, 2021; pp. 239-248.

46. Korstanje, M.; George, B. Demarketing overtourism. In Overtourism and Tourism Education: A Strategy for Sustainable tourism Futures; Seraphin, H., Yallop, A.C., Eds.; Routledge: Abingdon, UK, 2021; pp. 81-95.

47. Prideaux, B.; Pabel, A. Degrowth as a strategy for adjusting to the adverse impacts of climate change in a nature-based destination. In Tourism and Degrowth: New Perspectives on Tourism Entrepreneurship, Destinations and Policy; Hall, C.M., Lundmark, L., Zhang, J.J., Eds.; Routledge: Abingdon, UK, 2021; pp. 116-130.

48. Kotler, P.; Levy, S.J. Demarketing? Yes, demarketing! Harvard Bus. Rev. 1971, 49, 74-80.

49. Kim, S.; Ko, E.; Kim, S.J. Fashion brand green demarketing: Effects on customer attitudes and behavior intentions. J. Glob. Fash. Mark. 2018, 9, 364-378. [CrossRef]

50. Seeletse, S.M. Demarketing strategy to develop perceived product reputation: Applications in three distinct environments. Probl. Perspect. Manag. 2016, 14, 230-235.

51. Lawther, S.; Hastings, G.; Lowry, R. De-marketing: Putting Kotler and levy's ideas into practice. J. Mark. Manag. 1997, 13, 315-325. [CrossRef]

52. Kotler, P. The major tasks of marketing management. J. Mark. 1973, 37, 42-49. [CrossRef]

53. Peattie, K.; Peattie, S.; Newcombe, R. Unintended consequences in demarketing antisocial behaviour: Project Bernie. J. Mark. Manag. 2016, 32, 1588-1618. [CrossRef]

54. Chaudhry, P.E.; Cesareo, L.; Pastore, A. Resolving the jeopardies of consumer demand: Revisiting demarketing concepts. Bus. Horizons 2019, 62, 663-677. [CrossRef]

55. Landreat, M.G.; Dany, A.; Le Reste, J.Y.; Le Goff, D.; Benyamina, A.; Grall-Bronnec, M.; Gallopel-Morvan, K. Impact of alcohol marketing on drinkers with Alcohol use disorders seeking treatment: A mixed-method study protocol. BMC Public Health 2020, 20, 467-468. [CrossRef]

56. Bradley, N.; Blythe, J. Demarketing; Routledge: Abingdon, UK, 2014.

57. Soule, C.A.A.; Reich, B.J. Less is more: Is a green demarketing strategy sustainable? J. Mark. Manag. 2015, 31, 1403-1427. [CrossRef]

58. Groff, C. Demarketing in park and recreation management. Manag. Leis. 1998, 3, 128-135. [CrossRef]

59. Beeton, S.; Benfield, R. Demand control: The case for demarketing as a visitor and environmental management tool. J. Sustain. Tour. 2002, 10, 497-513. [CrossRef]

60. Beeton, S. Swimming against the tide: Integrating marketing with environmental management via demarketing. J. Hospitality Tour. Manag. 2003, 10, 95-107.

61. Beeton, S. Sustainable tourism in practice: Trails and tourism. Critical management issues of multi-use trails. Tour. Hosp. Plan. Dev. 2006, 3, 47-64. [CrossRef]

62. Medway, D.; Warnaby, G.; Dharni, S. Demarketing places: Rationales and strategies. J. Mark. Manag. 2010, 27, 124-142. [CrossRef] 
63. Armstrong, E.K.; Kern, C.L. Demarketing manages visitor demand in the Blue Mountains National Park. J. Ecotourism 2011, 10, 21-37. [CrossRef]

64. Weiler, B.; Moyle, B.D.; Scherrer, P.; Hill, M. Demarketing an iconic national park experience: Receptiveness of past, current and potential visitors to selected strategies. J. Outdoor Recreat. Tour. 2019, 25, 122-131. [CrossRef]

65. Drugova, T.; Kim, M.-K.; Jakus, P.M. Marketing, congestion, and demarketing in Utah's National Parks. Tour. Econ. 2020, 1-20. [CrossRef]

66. Hesse, A.; Rünz, S. "Fly Responsibly": A case study on consumer perceptions of a green demarketing campaign. J. Mark. Commun. 2020, 1-21. [CrossRef]

67. Taylor, I. Travel Weekly. Available online: https://www.travelweekly.co.uk/articles/278587/tourism-destroying-cities-saysamsterdam-marketing-head (accessed on 1 January 2021).

68. Hall, C.M. Winter visitors' perceptions in popular nature destinations in Iceland. In Winter tourism: Trends and challenges; CABI Publishing: Wallingford, UK, 2019; pp. 212-227.

69. Sæpórsdóttir, A.D.; Hall, C.M.; Stefánsson, P. Senses by seasons: Tourists' perceptions depending on seasonality in popular nature destinations in Iceland. Sustainability 2019, 11, 3059. [CrossRef]

70. Sæpórsdóttir, A.D.; Hall, C.M.; Wendt, M. Overtourism in Iceland: Fantasy or reality? Sustainability 2020, 12, 7375. [CrossRef]

71. Orchiston, C.; Higham, J. Knowledge management and tourism recovery (de)marketing: The Christchurch earthquakes $2010-2011$. Curr. Issues Tour. 2016, 19, 64-84. [CrossRef]

72. Taks, M. Social sustainability of non-mega sport events in a global world1. Eur. J. Sport Soc. 2013, 10, 121-141. [CrossRef]

73. Seyfi, S.; Hall, C.M. Tourism, Sanctions and Boycotts; Routledge: London, UK, 2019.

74. Clark, M.; Wilkins, E.J.; Dagan, D.T.; Powell, R.; Sharp, R.L.; Hillis, V. Bringing forecasting into the future: Using Google to predict visitation in U.S. national parks. J. Environ. Manag. 2019, 243, 88-94. [CrossRef] [PubMed]

75. Benfield, R.W. "Good things come to those who wait": Sustainable tourism and timed entry at Sissinghurst Castle Garden, Kent. Tour. Geogr. 2001, 3, 207-217. [CrossRef]

76. Benfield, R. ; Garden Tourism; CABI: Wallingford, UK, 2013.

77. Black, G.S. A social approach for de-marketing sex tourism. Bus. Rev. 2010, 15, 33-41.

78. Beeton, S.; Pinge, I. Casting the holiday dice: Demarketing gambling to encourage local tourism. Curr. Issues Tour. 2003, 6 , 309-322. [CrossRef]

79. Oklevik, O.; Gössling, S.; Hall, C.M.; Steen Jacobsen, J.K.; Grøtte, I.P.; McCabe, S. Overtourism, optimisation, and destination performance indicators: A case study of activities in Fjord Norway. J. Sustain. Tour. 2019, 27, 1804-1824. [CrossRef]

80. Clements, M. Selecting tourist traffic by demarketing. Tour. Manag. 1989, 10, 89-94. [CrossRef]

81. McKercher, B.; Weber, K.; Du Cros, H. Rationalising inappropriate behaviour at contested sites. J. Sustain. Tour. 2008, 16, 369-385. [CrossRef]

82. Wearing, S.W.; Archer, D. Developing an approach to marketing and demarketing of tourism for protected area management. In Proceedings of the Parks and Leisure Australia 2005 National Conference, Current Issues: Future Challenges, Hobart, Tasmania, Australia, 9-13 October 2005.

83. Popp, M. Positive and negative urban tourist crowding: Florence, Italy. Tour. Geogr. 2012, 14, 50-72. [CrossRef]

84. Milano, C.; Cheer, J.M.; Novelli, M. Overtourism: A growing global problem. The Conversation. Available online: https: / / theconversation.com/overtourism-a-growing-global-problem-100029 (accessed on 1 January 2021).

85. Żemła, M. Reasons and consequences of overtourism in contemporary cities-Knowledge gaps and future research. Sustainability 2020, 12, 1729. [CrossRef]

86. McKinsey \& Company. Coping with Success: Managing Overcrowding in Tourism Destinations; World Travel and Tourism Council: London, UK, 2017.

87. World Tourism Organization. "Overtourism"?-Understanding and Managing Urban Tourism Growth beyond Perceptions, Executive Summary; UNWTO: Madrid, Spain, 2018.

88. Gössling, S.; Scott, D.; Hall, C.M. Inter-market variability in $\mathrm{CO}_{2}$ emission-intensities in tourism: Implications for destination marketing and carbon management. Tour. Manag. 2015, 46, 203-212. [CrossRef]

89. Harvey, M.; Kerin, R. Perspectives on demarketing during the energy crisis. J. Acad. Mark. Sci. 1977, 5, 327-338. [CrossRef]

90. Ramirez, E.; Tajdini, S.; David, M.E. The effects of proenvironmental demarketing on consumer attitudes and actual consumption. J. Mark. Theory Pr. 2017, 25, 291-304. [CrossRef]

91. Little, V.J.; Lee, C.K.C.; Nair, S. Macro-demarketing: The key to unlocking unsustainable production and consumption systems? J. Macromark. 2019, 39, 166-187. [CrossRef]

92. Magalhães, M.J.; De Magalhães, S.T.; Rodrigues, C.; Marques, S. Acceptance criteria in a promotional tourism demarketing plan. Procedia Comp. Sci. 2017, 121, 934-939. [CrossRef]

93. Wall, A. Government "demarketing" as viewed by its target audience. Mark. Intell. Plan. 2007, 25, 123-135. [CrossRef]

94. Fullerton, L.; Mcgettigan, K.; Stephens, S. Integrating management and marketing strategies at heritage sites. Int. J. Cult. Tour. Hosp. Res. 2010, 4, 108-117. [CrossRef]

95. Hall, C.M.; McArthur, S. Integrated Heritage Management; HMSO: London, UK, 1998.

96. SET, South Europe Cities Facing Touristification. Available online: https://www.ecologistasenaccion.org/94342/ciudades-yregiones-del-sur-de-europa-contra-la-turistizacion/ (accessed on 1 January 2021). 
97. Wearing, S.W.; Archer, D. Towards a framework for sustainable marketing of protected areas. Aust. Parks Leis. 2001, 4, 33-40.

98. Koens, K.; Postma, A. Understanding and Managing Visitor Pressure in Urban. Tourism. A Study into the Nature of and Methods Used to Manage Visitor Pressure in Six Major European Cities; Centre of Expertise Leisure, Tourism and Hospitality, Breda University of Applied Sciences: Stenden, The Netherlands, 2017.

99. Hall, C.M. Constructing sustainable tourism development: The 2030 agenda and the managerial ecology of sustainable tourism. J. Sustain. Tour. 2019, 27, 1044-1060. [CrossRef]

100. Nicolson, N. Portrait of a Marriage: V. Sackville-West and Harold Nicolson; Atheneum: London, UK, 1973.

101. Nicolson, A. Sissinghurst-An Unfinished History; Harper Press: London, UK, 2008.

102. Scott-James, A. Sissinghurst-The Making of a Garden; Michael Joseph: London, UK, 1974.

103. Eiseman, D. Marketing sustainable tourism: Principles and practice. In Tourism Planning and Destination Marketing; Camilleri, M.A., Ed.; Emerald: Cheltenham, UK, 2018; pp. 121-140.

104. Bellew, L. Sissinghurst Castle Garden Reopens Vita Sackville-West's Phlox Garden. Kentonline. Available online: https: //www.kentonline.co.uk/whats-on/news/turning-back-the-clock-with-129995/ (accessed on 1 January 2021).

105. House of Commons, Digital, Culture, Media and Sport Committee. Garden Design and Tourism, Fourteenth Report of Session 2017-19, Report, Together with Formal Minutes Relating to the Report, HC 2002; House of Commons: London, UK, 2019.

106. Aall, C.; Hall, C.M.; Groven, K. Tourism: Applying rebound theories and mechanisms to climate change mitigation and adaptation. In Rethinking Climate and Energy Policies; Santarius, T., Jakob, H., Aall, W.C., Eds.; Springer: Cham, Switzerland, 2016 ; pp. 209-225.

107. Hall, C.M.; Scott, D.; Gössling, S. The primacy of climate change for sustainable international tourism. Sustain. Dev. 2013, 21, 112-121. [CrossRef]

108. Kim, S.; Filimonau, V.; Dickinson, J.E. The technology-evoked time use rebound effect and its impact on pro-environmental consumer behaviour in tourism. J. Sustain. Tour. 2019, 28, 164-184. [CrossRef]

109. Murray, V.Q. Social Activist Marketing: A reconceptualization of countermarketing and demarketing. J. Nonprofit Public Sect. Mark. 1997, 5, 3-25. [CrossRef]

110. Fletcher, R.; Mas, I.M.; Blanco-Romero, A.; Blázquez-Salom, M. Tourism and degrowth: An emerging agenda for research and praxis. J. Sustain. Tour. 2019, 27, 1745-1763. [CrossRef]

111. Higgins-Desbiolles, F.; Carnicelli, S.; Krolikowski, C.; Wijesinghe, G.; Boluk, K. Degrowing tourism: Rethinking tourism. J. Sustain. Tour. 2019, 27, 1926-1944. [CrossRef] 